\title{
Colonization of the Arctic Ocean by two cosmopolitan genera of marine invertebrates
}

\author{
N.E. Budaeva ${ }^{1}$, A.V. Rogacheva ${ }^{2}$ \\ P.P. Shirshov Institute of Oceanology, Russian Academy of Sciences, Nakhimovsky Prospekt, 36, \\ 117997, Moscow, Russia \\ ${ }^{1}$ e-mail: nataliya.budaeva@gmail.com \\ 2e-mail: antonina@ocean.ru
}

\begin{abstract}
The colonization of the Arctic Ocean by two genera of marine invertebrates widely-distributed outside the Arctic, Paradiopatra, a polychaete, and Elpidia, a holothurian, is described using methods of phylogenetic biogeography, including morphologybased phylogenetic reconstruction. The phylogeny of Elpidia was reconstructed based on a matrix of 20 morphological characters for 22 species. Maximum parsimony analysis yielded four equally parsimonious trees within the Arctic clade, comprising three species: E. belyaevi, E. glacialis and E. heckeri. Elpidia gracilis inhabiting the north Atlantic was the sister species to the Arctic clade on three of four most parsimonious tress. This suggests possible colonization of the Arctic Ocean from the North Atlantic. Comparison of pairs of species of Paradiopatra: P. striata/P. pauli and P. yasudai/P. quadricuspis supports the hypothesis of trans-Arctic faunal exchange. These pairs form monophyletic clades on the strict consensus tree and have representatives in the Pacific and the Arctic/North Atlantic. It is argued that dispersal of fauna most probably was directed from the north Pacific to the North Atlantic across the Arctic. Two North Atlantic species, P. fiordica and P. quadricuspis, with almost identical geographical and vertical ranges along the boundary between the North Polar Region and the Eastern Atlantic Boreal Region did not form the monophylectic clade on the phylogenetic tree and were considered as distant relatives. However the strict consensus tree had very low resolution due to high portion of homoplastic characters and relationships of the species could not be tested exhaustively.
\end{abstract}

KEY WORDS: Paradiopatra, Elpidia, phylogeny, biogeography, trans-Arctic interchange.

\section{Колонизация Северного Ледовитого океана двумя широко распространенными родами морских беспозвоночных}

\author{
Н.Е. Будаева ${ }^{1}$, А.В. Рогачева ${ }^{2}$
}

Федеральное государственное бюджетное учреждение науки Институт океанологии им. П.П. Шириова Российской академии наук, Нахимовский пр., 36, 117997, Москва, Россия.

${ }^{1}$ e-mail: nataliya.budaeva@gmail.com

2 e-mail: antonina@ocean.ru

РЕЗЮМЕ: На основе реконструкции филогенетических отношений с использованием морфологических признаков и методов филогенетической биогеографии описаны 
пути колонизации Северного Ледовитого океана двумя широко распространенными родами морских беспозвоночных: многощетинковыми червями Paradiopatra и голотуриями Elpidia. Филогения рода Elpidia была получена на основе матрицы из 20 морфологических признаков, закодированных для 22 видов. В результате анализа, проведенного методом максимальной экономии, было получено четыре равно экономных дерева. На каждом дереве присутствовала клада, объединяющая арктические виды: E. belyaevi, E. glacialis и E. heckeri. На трех максимально экономных деревьях вид E. gracilis, населяющий северную Атлантику, имел сестринское положение по отношению к арктической кладе, что позволило предположить возможный путь заселения Арктики из северной Атлантики. Сравнение пар видов из рода Paradiopatra: P. striata/P. pauli и P. yasudai/P. quadricuspis поддерживает гипотезу о трансарктическом обмене фаунами. Эти пары видов образуют монофилетические группировки на строгом консенсусном дереве, и каждая из них включают в себя виды, обитающие в северной Пацифике и в Арктике/северной Атлантике. Высказывается предположение о том, что вероятный путь расселения видов был направлен из северной Пацифики через Арктику в северную Атлантику. Два североатлантических вида $P$. fiordica и $P$. quadricuspis с практически полностью совпадающими ареалами и диапазонами вертикального распространения вдоль границы между Северной Полярной Областью и Восточноатлантической Бореальной Областью не показали близкородственных отношений при анализе филогении рода. Однако строгое консенсусное дерево имело низкое разрешение в виду большого количества гомопластических признаков, и поэтому анализ филогенетических отношений в роде не смог выявить все родственные связи.

КЛЮЧЕВЫЕ СЛОВА: Paradiopatra, Elpidia, phylogeny, biogeography, trans-Arctic faunal interchange.

\section{Introduction}

The Arctic Ocean has played a significant role in biotic interchange between the North Atlantic and the North Pacific since the early Pliocene (Palumbi, Kessing, 1991; Vermeij, 1991; Wares, Cunningham, 2001; Addison, Hart, 2005). The asymmetry of trans-Arctic invasion was suggested in a number of studies published during recent decades. According to Durham and MacNeil (1967), the number of species dispersed from the Pacific to the Atlantic is eight times higher than that in the opposite direction. However the analysis of the pattern of trans-Arctic species dispersion shows a strong bias in favour of species of the Pacific origin (Vermeij, 1991).

While the dominance of Pacific fauna in the trans-Arctic interchange is generally accepted, the ratio of species of Atlantic and Pacific origin in the Arctic Ocean still remains questionable.
Ekman (1935) and Gurjanova (1939) analysed endemic fauna of the high-latitude Arctic waters and suggested the role of the Pacific Ocean as donor of species greatly exceeding the role of the Atlantic Ocean. The dominance of species of the Pacific origin was also accepted by Djakonov (1945), Mironov and Dilman (2010), while Anisimova (1989) and Smirnov (1994) suggest a dominance of species of Atlantic origin. The multivariate analysis of deep-sea occurrences of polychaete species off the Eurasian and American coasts of the Arctic Ocean and the Greenland-Iceland-Norwegian Seas revealed strong Atlantic influence and absence of modern Pacific fauna (Bluhm et al., 2011). The occurrence of the Arctic-Atlantic Region in a number of schemes of biogeographical subdivision(Gontar, Denisenko, 1989; Kussakin, 1979; Petryashov, 2009) underlines the close relationships between the Arctic and the North Atlantic. However more studies of historical biogeogra- 
phy of various genera are required to clarify the ratio of Atlantic and Pacific components in the modern Arctic fauna.

Three major approaches are traditionally used to reveal possible pathways of colonization of the Arctic Ocean: paleontological, morphological and molecular. Analysis of paleontological data and comprehensive molecular studies provide reliable evidence on possible schemes of trans-Arctic faunistic exchange (Palumbi, Kessing, 1991; Collins et al., 1996; Harrison, Crespi, 1999; Wares, 2001; Väinölä, 2003; Dodson et al., 2007). However the number of paleontological records in the Arctic remains limited. Molecular data for many marine taxa are rarely available because of difficulties with obtaining ethanol fixed, or frozen, material from relevant geographical areas. Morphological studies based on phylogenetic approaches may provide additional information on the colonization of the Arctic Ocean and faunistic interchange.

The main goal of the present study is to evaluate possible pathways of species dispersal in the northern hemisphere, with emphasis on colonization of the Arctic region based on studies of phylogeny in two genera of benthic invertebrates: Paradiopatra (Onuphidae, Polychaeta, Annelida) and Elpidia (Elpidiidae, Holothuroidea, Echinodermata). Both genera are widely distributed in the world ocean from subtidal to hadal depths (Belyaev, 1971; Budaeva, Fauchald, 2011), and have representatives in the Arctic, the North Pacific and the North Atlantic. A phylogeny of the genus Paradiopatra has been proposed by Budaeva and Fauchald (2011) and the present study was based on this. A revision of Elpidia was published by Belyaev (1971, 1975), who recognized several species groups based on morphological similarities, and a revision of the Arctic group of species of Elpidia was conducted by Rogacheva (2007).

\section{Materials and Methods}

Possible pathways of species dispersal in the Arctic Ocean were studied using phylogenetic biogeography. The term "phylogenetic bioge- ography" was proposed by Brundin (1966, 1972), who suggested using the phylogenetic reconstruction of a monophyletic taxon to understand its biogeographical history (Crisci et al., 2003). This method is rather descriptive and has a number of restrictions, such as the allopatric speciation and the ad hoc assumption about a centre of origin corresponding to geographical range of the most basal taxon in the examined monophyletic clade (Crisci et al., 2003). Nevertheless, the method allows utilization of a robust hypothesis of phylogenetic relationships within the analyzed monophyletic group of species to support suggested potential pathways of dispersal.

In the present study, we consider the Arctic Ocean to be bounded by the Greenland-IcelandFaeroe Ridge in the Atlantic and the Bering Strait in the Pacific. The shelf areas of the Arctic, excluding the shelf of the Norwegian Sea, belong to the North Polar (or Arctic) Shelf Region (Briggs, 1974, 1995). The deep-sea areas of the Arctic, including the Norwegian and Greenland Basins, form a separate biogeographical unit of disputed rank. Biogeographical subdivision of the Arctic is discussed in more detail by Mironov (present volume).

The genus Paradiopatra (Onuphidae, Polychaeta) comprises 26 species including species previously assigned to the genus Notonuphis Kucheruk, 1987 (for details see Budaeva, Fauchald, 2011). The phylogenetic tree for the genus Paradiopatra was obtained from Budaeva and Fauchald (2011).

Characters for the phylogenetic analysis of Elpidia were obtained from unpublished original and published data. Species were examined using a compound microscope. A matrix comprising 20 morphological characters, coded over 22 terminal taxa (including 21 ingroups and one outgroup), was constructed using DELTA Editor (DEscription Language for TAxonomy, Dallwitz et al., 1999) (Table 1). All characters were treated as non-additive with equal weights. Multistate characters were treated as unordered. Polymorphic characters were included in the original matrix. Inapplicable character states were coded as '-', unknown character states as 


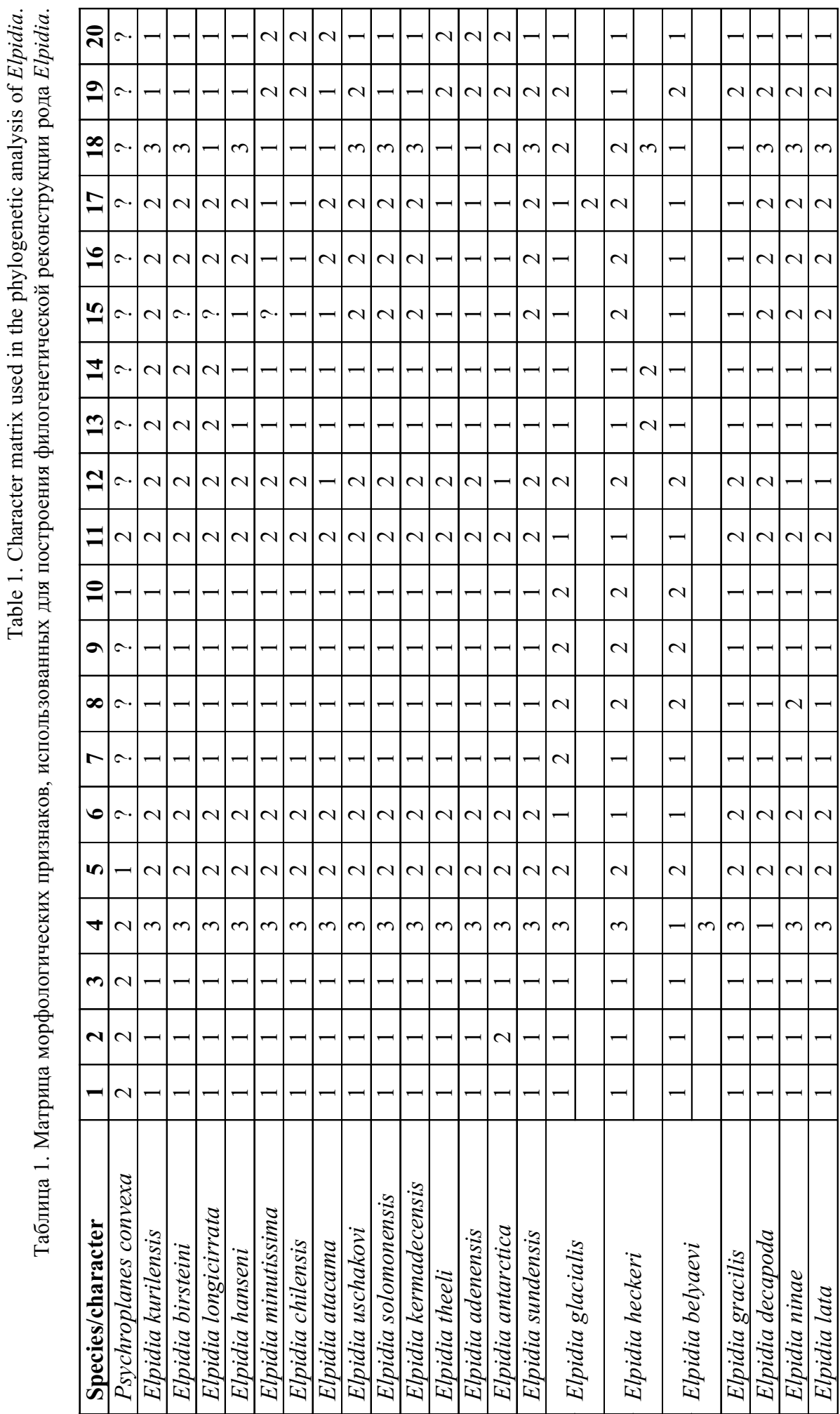


'?'. Maximum parsimony analysis, examination of cladogram topologies and character evolution was performed in Winclada (Nixon, 2002). The search for the most parsimonious trees was heuristic, using TBR (tree bisection and reconnection) + TBR algorithm with 1000 replicates and 100 trees held on each step. The results of parsimony analysis were summarized into strict and $50 \%$ majority rule consensus trees. The outgroup method was used for tree rooting.

The geographical ranges of all known species of Paradiopatra and Elpidia were analysed to understand the distribution patterns of both genera in the North Pacific, the North Atlantic and the Arctic. Phylogenetic reconstructions of intrageneric relationships within the genera $E l$ pidia and Paradiopatra (Budaeva, Fauchald, 2011) were used for biogeographical implications.

\section{Results}

\subsection{Phylogeny of Elpidia}

\subsubsection{Taxon sampling}

Elpidia is one of 13 genera in the family Elpidiidae. The genus Elpidia comprises 21 species. Elpidia javanica Belyaev, 1971 is considered here as synonym of E. sundensis Hansen, 1956. Several species in Belyaev (1971) were designated unnamed Elpidia sp.1 to sp.5. Elpidia sp. 1 is now assigned to E. belyaevi. Other unnamed species are known from fragments or specimens in poor condition and could not be used in the phylogenetic analysis.

The ingroup included all the 21 described species of Elpidia. Morphological data were obtained from the literature for the following species: E. adenensis Belyaev, 1971; E. antarctica Belyaev, 1971; E. atakama Belyaev, 1971; E. birsteini Belyaev, 1971; E. chilensis Belyaev, 1971; E. decapoda Belyaev, 1975; E. glacialis Théel, 1976; E. hanseni Belyaev, 1971; E. kermadecensis Hansen, 1956; E. kurilensis Baranova et Belyaev, 1971; E. lata Belyaev, 1975; E. longicirrata Belyaev, 1971; E. minutissima Belyaev, 1971; E. ninae Belyaev, 1975; E. solomonensis Hansen, 1956; E. sundensis Hansen, 1956; E. theeli Hansen, 1956 and E. uscha- kovi Belyaev, 1971 (Heding, 1942; Hansen, 1956, 1975; Belyaev, 1971, 1975; Gebruk, 1993; Rogacheva, 2007).

Three species were examined during this study:

E. belyaevi Rogacheva, 2007

Material examined: BIOICE, St. $2772,69.26^{\circ} \mathrm{N} 14.22^{\circ}$ W, $1633 \mathrm{~m}, 3.08 .1995,13$ specimens; BIOICE, St. 2773, $69.25^{\circ} \mathrm{N} 14.28^{\circ} \mathrm{W}, 1629-1630 \mathrm{~m}, 3.08 .1995,151$ specimens; BIOICE, St. $2776,68.6^{\circ} \mathrm{N} 14.67^{\circ} \mathrm{W}, 1553-$ $1556 \mathrm{~m}, 3.08 .1995,4$ specimens.

E. gracilis Belyaev, 1975

Material examined: Discovery, St. $9754 \# 3,51^{\circ} 8^{\prime} \mathrm{N}$ $12^{\circ} 2^{\prime}$ W, $1484 \mathrm{~m}, 1978,7$ specimens; Discovery, St. 9753\#7, $50^{\circ} 55^{\prime} \mathrm{N} 12^{\circ} 12^{\prime} \mathrm{W}, 1942 \mathrm{~m}, 1978,40$ specimens; Challenger, St. 50602\#2, $51^{\circ} 1^{\prime} \mathrm{N} 13^{\circ} 7^{\prime} \mathrm{W}, 1980 \mathrm{~m}, 1979$,

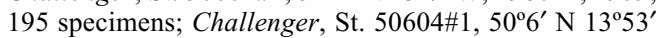
W, 3490-3550 m, 1979, 2 specimens; Discovery, St. $9756 \# 14,50^{\circ} 4^{\prime} \mathrm{N} \mathrm{13}{ }^{\circ} 54^{\prime} \mathrm{W}, 3697-3680 \mathrm{~m}, 1978,1$ specimen; Challenger, St. 50603\#1, $49^{\circ} 46^{\prime} \mathrm{N} 14^{\circ} 2^{\prime} \mathrm{W}$, $4000 \mathrm{~m}, 1979,2$ specimens.

E. heckeri Baranova, 1989

Material examined: BIOICE, St. $3203,64.85^{\circ} \mathrm{N} 7.86^{\circ}$ W, 2612-2605 m, 8.07.2001, 137 specimens and fragments; BIOICE, St. $3204,64.86^{\circ} \mathrm{N} 7.91^{\circ} \mathrm{W}, 2613-2611$ $\mathrm{m}$, 8.07.2001, 8 specimens.

Psychroplanes convexa (Hansen, 1975) was selected as an outgroup. Ossicles in $P$. convexa are cross-shaped, a feature also characteristic of Elpidia antarctica. Psychroplanes is considered as one of the most primitive genera of Elpidiidae (Gebruk, 1990, 1993).

\subsubsection{Description of characters}

(1) Velum

Velum represents dorsal papillae that may be partly or completely fused along their length. Velum appears in many elpidiid genera such as Peniagone, Psychroplanes, Achlyonice, Kolga and Amperima, and is absent in Elpidia, Scotoplanes and Protelpidia.

(2) Cross-shaped ossicles

The presence of cross-shaped ossicles is one of the main diagnostic characters of the suborder Psychropotina, including the families Psychropotidae, Elpidiidae and Pelagothuriidae. According to Hansen (1975) and Gebruk (1990) cross-shaped ossicles are more primitive than tripartite, rod-shaped and Elpidia-type ossicles (see below) and they derive from primary crosses, the original type of most holothurian ossicles. Only few elpidiid genera have cross-shaped 
ossicles: Rhipidothuria, Psychrelpidia, Psychroplanes and Peniagone. Within Elpidia one species, E. antarctica, displays cross-shaped ossicles.

\section{(3, 13-20) Ossicles of the Elpidia-type}

This type of ossicles is found in all Elpidia species and also in Penilpidia and Protelpidia. Elpidia-type ossicles are rods with two pairs of horizontal arms and one pair of vertical apophyses. Vertical apophyses may be reduced in some species. The Elpidia species differ from each other in the shape and size of the ossicles.

(4) Tube feet

Tube feet in elasipodids correspond to large ambulacral appendages forming rows along ventrolateral radii. Elpidia has the lowest number of tube feet in the Elpidiidae, four, or rarely five, pairs. The highest number of tube feet (more than 20 pairs) ocurrs in Psychrelpidia discrepans.

(5) Calcareous ring

The calcareous ring of elpidiids consists of five radial pieces, each with two clusters of long arms radiating from a common centre. The number of arms can be constant, e.g. four in Elpidia and Scotoplanes, or varying, as in most of other genera.

\section{(6-11) Dorsal papillae}

Papillae in elasipodids correspond to ambulacral appendages on right and left dorsal radii. Papillae in all species of Elpidia, except $E$. javanica, differ in shape and arrangement. $E$. javanica lacks papillae.

\section{(12) Anus}

The anus in elpidiids can be dorsal, ventral or terminal. In Elpidia the anus is terminal/ subterminal or ventral.

\subsubsection{Characters and their states}

1. Velum: (1) absent; (2) present.

2. Cross-shaped ossicles: (1) absent; (2) present.

3. Elpidia-type ossicles: (1) absent; (2) present.

4. Maximum number of tube feet, pairs: (1) 5 ; (2) more than 5 ; (3) 4.

5. Number of arms in cluster on segments of the calcareous ring: (1) 7; (2) 4.
6. Anterior and posterior groups of papillae: (1) absent; (2) present.

7. Arrangement of papillae in anterior half of body: (1) papillae placed separately and never fuse; (2) papillae placed closely and fused at the basis.

8. Comparative length of papillae in the anterior half of the dorsum: (1) papillae not decreasing gradually; (2) papillae decreasing in length towards the middle of dorsum.

9. Length of the first (anterior) and the last (posterior) pairs of papillae: (1) papillae of the first and the last pairs are different in length, or all papillae are almost of the same length; (2) papillae of the first pair are of the same length as papillae of the last pair, other papillae are shorter.

10. Relative length of anteriormost and posteriormost papillae: (1) anteriormost and posteriormost papillae differ in length, or are the same length but not the longest; (2) anteriormost and posteriormost papillae are the longest and of the same length.

11. Papillae on mid dorsum: (1) absent; (2) present.

12. Location of anus: (1) ventral; (2) terminal or subterminal.

13. Dorsal or ventral ossicles without vertical apophyses: (1) absent or occur occasionally; (2) present in $>10 \%$ of preparations.

14. Vertical apophyses: (1) ossicles with two apophyses dominate; (2) ossicles without apophyses dominate.

15. Relative length of vertical apophyses: (1) $>15 \%$ of the rod length; (2) $<15 \%$ of the rod length.

16. Relative diameter of rods: (1) rods enlarged between horizontal arms; (2) rods not enlarged between horizontal arms.

17. Bases of horizontal arms: (1) spaced distantly; (2) located close to each other with acute angle in some or in many ossicles.

18. Ends of rods and arms; (1) pointed, only few small spines can be present; (2) enlarged, no spines or sometimes few very small spines; (3) enlarged or bear numerous large spines.

19. Relative length of horizontal arms: (1) arms may differ in length up to 2 times; (2) arms almost of the same length. 


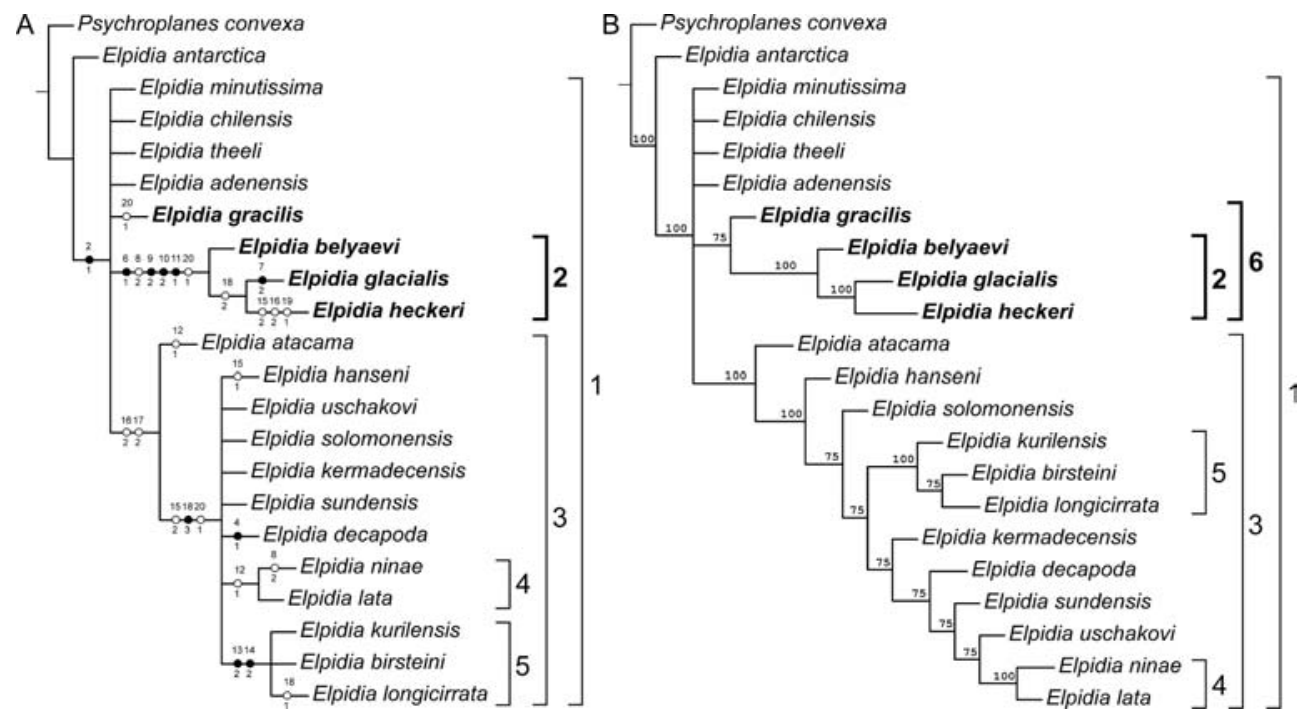

Fig. 1. Phylogenetic reconstruction of Elpidia.

A - strict consensus tree of four equally parsimonious trees. B - majority rule (50\%) consensus tree of four equally parsimonious trees. White circles represent homoplastic synapomorphies, black circles are exclusive synapomorphies. Upper rows of numbers represent character numbers corresponding to the matrix; lower rows of numbers represent states of respective characters. Node numbers represent frequency values for each node. Numbers beside square brackets represent clades discussed in the text.

Рис. 1. Филогенетическая реконструкция отношений в роде Elpidia.

А - строгое консенсусное дерево, построенное на основе четырех равноэкономных деревьев. В - консенсусное дерево, построенное на основе четырех равноэкономных деревьев по методу правила большинства (50\%). Белыми кружками обозначены гомопластические синапоморфии, черными кружками обозначены уникальные синапоморфии. Верхние ряды цифр на ветвях дерева А соответствуют номерам признаков в матрице, нижние ряды цифр обозначают состояния соответствующих признаков. Значения в узлах дерева В указывают на процент максимально экономных деревьев, у которых присутствует данный узел. Номера за квадратными скобками соответствуют обозначениям клад в тексте.

20. Rod diameter in the middle of largest ossicles: (1) $>35 \mu \mathrm{m}$; (2) $<35 \mu \mathrm{m}$.

\subsubsection{Phylogenetic interrelationships}

Phyloginetic analysis yielded four equally parsimonious trees with a length of 33 steps, $\mathrm{Ci}=66, \mathrm{Ri}=81$. The strict consensus tree was 37 steps in length $(\mathrm{Ci}=59, \mathrm{Ri}=75)$ with $E$. antarctica as the most basal species of the genus (Fig. 1A). This species differed from the others by the presence of cross-shaped ossicles (character 2). Clade 1 contained polytomy of five species with clades 2 and 3 (Fig. 1A). Clade 2 (Fig. 1A) consisted of three species E. belyaevi, E. glacialis and E. heckeri. Clade 3 included several clades with species mostly occurring in deepsea trenches. Among them species from the
South Sandwich Trench (clade 4) and the NorthEast Pacific Trenches (clade 5) (Fig. 1A).

Our analysis was focused on clade 2 containing three Arctic species. The monophyly of this clade is supported by four exclusive synapomorphies: the presence of anterior and posterior groups of papillae (character 6), equal length of the longest anteriormost papillae (characters 8 and 9), and absence of papillae on mid-dorsum (character 11). E. belyaevi was the most basal species within the Arctic clade 2 (Fig. 1A). The placement of clade 2 cannot be established with confidence in the strict consensus tree because of the lack of basal resolution. The $50 \%$ majority rule consensus tree showed Arctic species combined with $E$. gracilis in a single clade as well as MPT1-3 (Figs. 1B; 2A-C). 

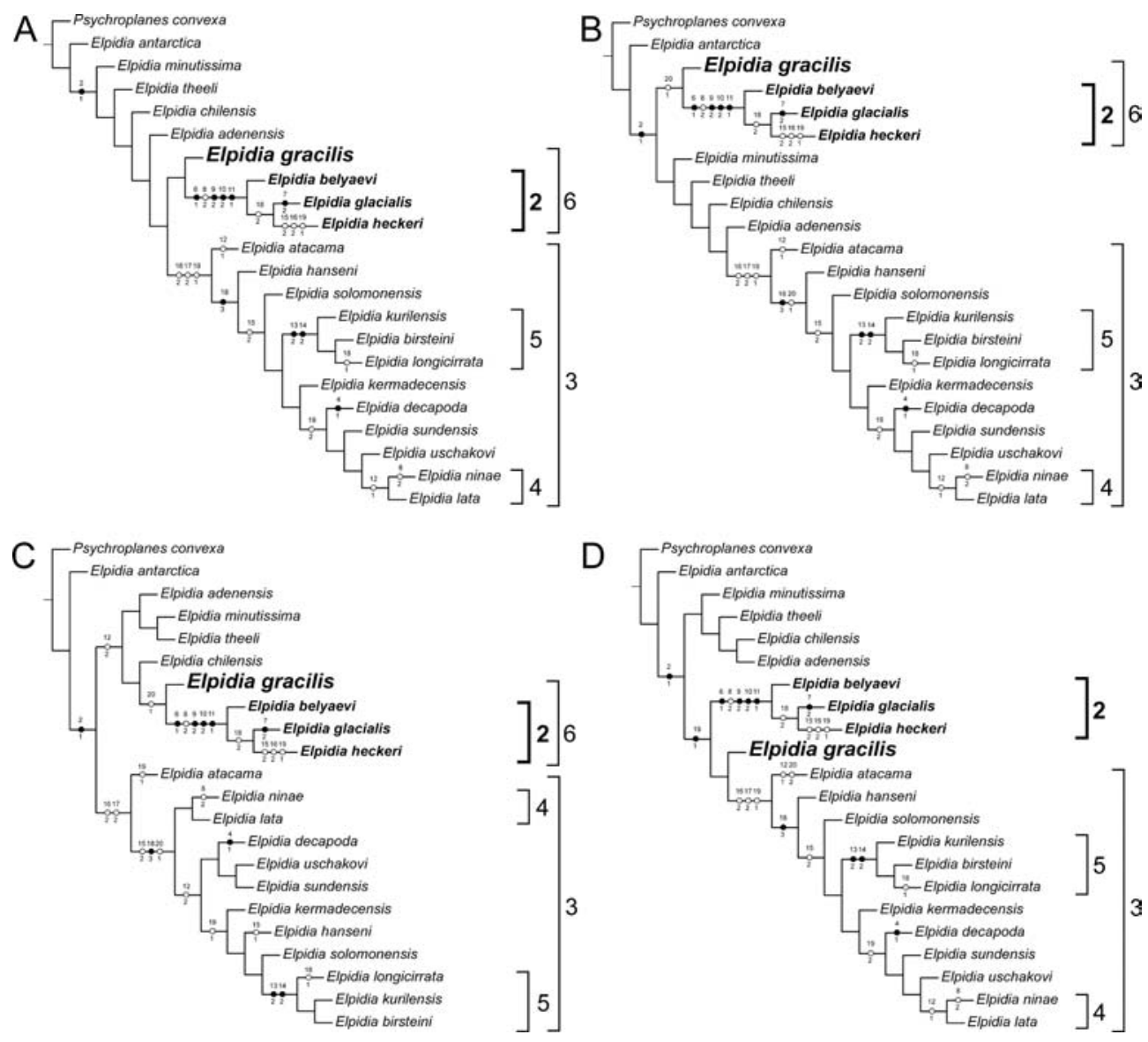

Fig. 2. Phylogenetic reconstruction of Elpidia. Four equally parsimonious trees (I-IV).

Рис. 2. Филогенетическая реконструкция отношений в роде Elpidia. Четыре максимально экономных дерева (А-D).

\subsection{Phylogeny of Paradiopatra}

Although the genus Paradioptra was present as a monophyleic clade on the strict consensus tree, the basal polytomy indicated very low resolution within the genus (Budaeva, Fauchald, 2011). Nevertheless two clades comprising, four species distributed in the northern hemisphere, can be recognized. P. quadricuspis and P. yasudai formed monophyletic clade 1 (Fig. 3) sharing the following characters: presence of branchiae starting from chaetigers 6-8; lateral projection of anterior parapodia from the body; two pairs of cirriform ventral cirri modifying into indistinct transverse glandular fields on the subsequent several chaetigers; and extremely long sharply pointed hoods on anterior pseudocompound chaetae. $P$ pauli and $P$. striata were combined into the clade 2 (Fig. 3) based on three synapomorphies: very short lateral and median antennae; start of branchiae from chaetigers 68; and lateral projection of the anterior parapodia (Budaeva, Fauchald, 2011). 


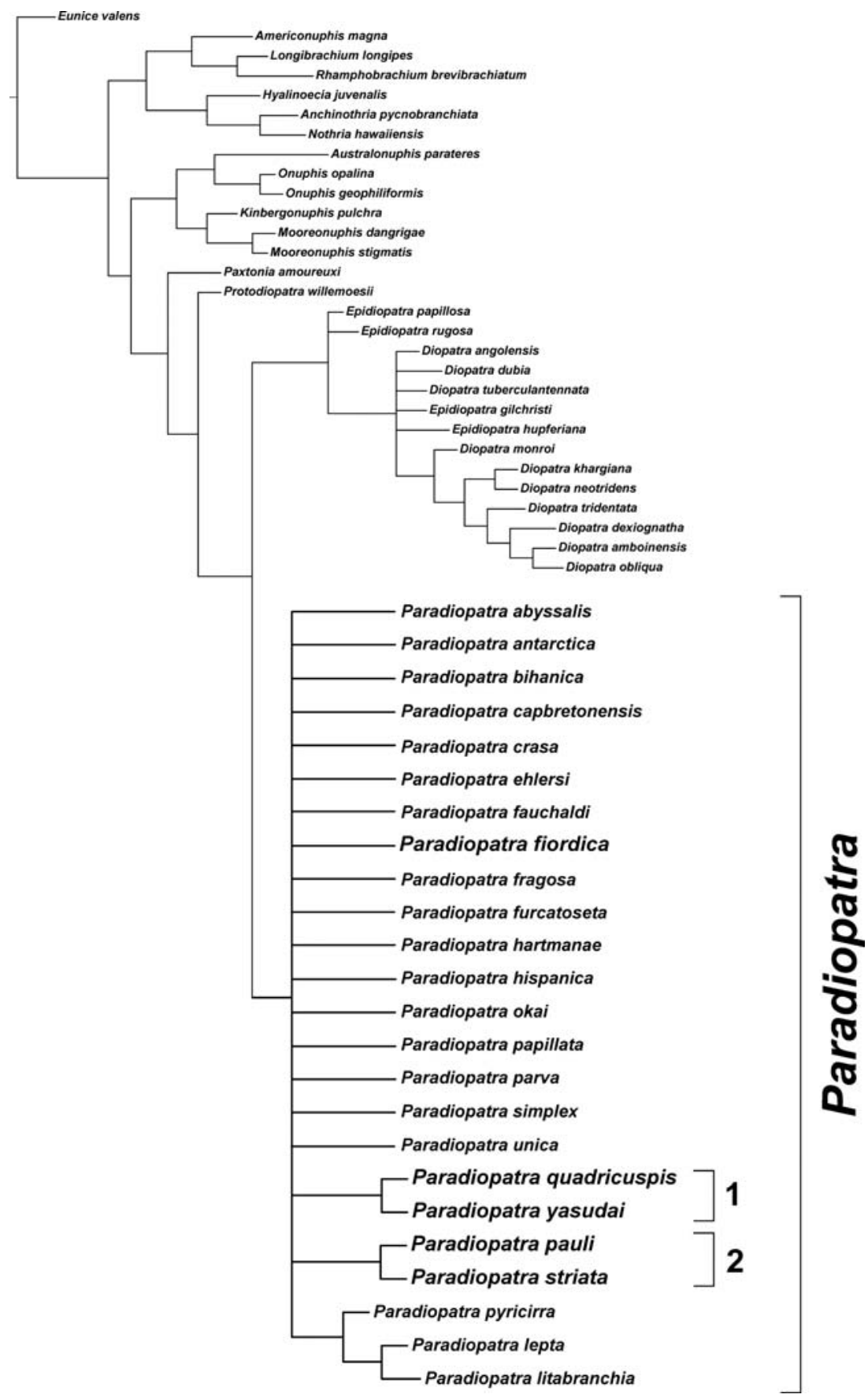

Fig. 3. Phylogenetic reconstruction of Paradiopatra. Strict consensus tree of 1525 equally parsimonious trees. Numbers beside square brackets represent clades used in the text (modified from Budaeva, Fauchald, 2011).

Рис. 3. Филогенетическая реконструкция отношений в роде Paradiopatra. Строгое консенсусное дерево, построенное на основе 1525 равноэкономных деревьев. Номера за квадратными скобками соответствуют обозначениям клад в тексте (с изменениями из Budaeva, Fauchald, 2011). 
Table 2. Distribution patterns of Elpidia and Paradiopatra in the Northern Hemisphere. Таблица 2. Распространение Elpidia и Paradiopatra в северном полушарии.

\begin{tabular}{|c|c|c|c|}
\hline Characters & $\begin{array}{l}\text { North Pacific, } \\
\text { north of } 30^{\circ} \mathbf{N}\end{array}$ & $\begin{array}{l}\text { Arctic Ocean, including } \\
\text { the Norwegian } \\
\text { and the Chukchi Seas }\end{array}$ & $\begin{array}{l}\text { North Atlantic, } \\
\text { north of } 30^{\circ} \mathrm{N}\end{array}$ \\
\hline \multicolumn{4}{|c|}{ Elpidia } \\
\hline $\begin{array}{l}\text { Number of } \\
\text { species }\end{array}$ & 5 & 3 & 1 \\
\hline Depths, m & $4100-9530$ & $70-5550$ & $1484-4000$ \\
\hline $\begin{array}{l}\text { Species } \\
\text { ranges }\end{array}$ & $\begin{array}{l}\text { Arctic-North Pacific } \\
-0 \\
\text { Endemic }-3 \\
\text { Others }-2\end{array}$ & Endemic (Arctic) - 3 & $\begin{array}{l}\text { Arctic-North } \\
\text { Atlantic - } 0 \\
\text { Endemic - } 0 \\
\text { Others - } 1\end{array}$ \\
\hline \multicolumn{4}{|c|}{ Paradiopatra } \\
\hline $\begin{array}{l}\text { Number of } \\
\text { species }\end{array}$ & 14 & 3 & 9 \\
\hline Depths, $m$ & $15-6350$ & $68-1125$ & $67-6350$ \\
\hline $\begin{array}{l}\text { Species } \\
\text { ranges }\end{array}$ & $\begin{array}{l}\text { Arctic-North Pacific } \\
-0 \\
\text { Endemic }-10 \\
\text { Disjunctive Pacific- } \\
\text { Atlantic (boreal) - } \\
1 \\
\text { Others }-3\end{array}$ & $\begin{array}{l}\text { Arctic-North Atlantic (boreal) } \\
-2 \\
\text { Endemic, near-Pacific (low- } \\
\text { arctic) }-1\end{array}$ & $\begin{array}{l}\text { Arctic-North } \\
\text { Atlantic (boreal) } \\
-2 \\
\text { Endemics - } 3 \\
\text { Disjunctive } \\
\text { Pacific-Atlantic } \\
\text { (boreal) - } 1 \\
\text { Others -3 }\end{array}$ \\
\hline
\end{tabular}

\subsection{Distribution patterns of Paradi-} opatra and Elpidia in the North Pacific, North Atlantic and Arctic

In the present study we focused on species inhabiting temperate and cold-water areas of the Northern Hemisphere. Species occurring in the Arctic, the North Atlantic and the North Pacific were also considered as markers of possible dispersal pathways. Distribution patterns and relationships among other species in both genera were beyond the scope of the present study and thus will not be discussed herein. The general biogeographical patterns of the genera $E l$ pidia and Paradiopatra in the high latitudes of the Northern Hemisphere are shown in Table 2.

Species of Elpidia are widely distributed in the Arctic. Three species are endemic to the Arctic Ocean. The bathyal species, E. belyaevi, and the bathy-abyssal, E. heckeri, occur in the Norwegian-Greenland basin and in the Central Arctic (Fig. 4). E. belyaevi is also known from the Baffin Bay. The shallow-water species, $E$. glacialis, is distributed in the Kara Sea, the Barents Seas and the fjords of Greenland and Svalbard.
In contrast to Elpidia, species of Paradiopatra are narrowly distributed in the Arctic Ocean, inhabiting only near-Atlantic and nearPacific sectors. Four Paradiopatra species were chosen based on their possible role in transArctic fauna interchange that took place during the climate warming in the early Pliocene (Fig. 5). P. pauli is the single species in the genus reported exclusively from the Arctic Ocean, occurring in the northern part of the Chukchi Sea at depths 68-445 m (Annenkova, 1952; Budaeva, Fauchald, 2011). The geographical range $P$. quadricuspis is restricted to the Norwegian coast and off south-west Iceland, depth range from 154 to $780 \mathrm{~m}$ (Budaeva, Fauchald, 2011).

P. striata is commonly found in the Bering Sea and off Kamchatka (Budaeva, Fauchald, 2011), and reported by Imajima (1999) from Japan. This species has also been found in the north-west Atlantic off Nova Scotia (depth range from 17 to $1660 \mathrm{~m}$ ), thus showing an amphiboreal geographical distribution. P. yasudai occurs in the north Pacific (in Japanese waters) at sublittoral and upper bathyal depths (from 60 to 960 m) (Imajima, 1999). 


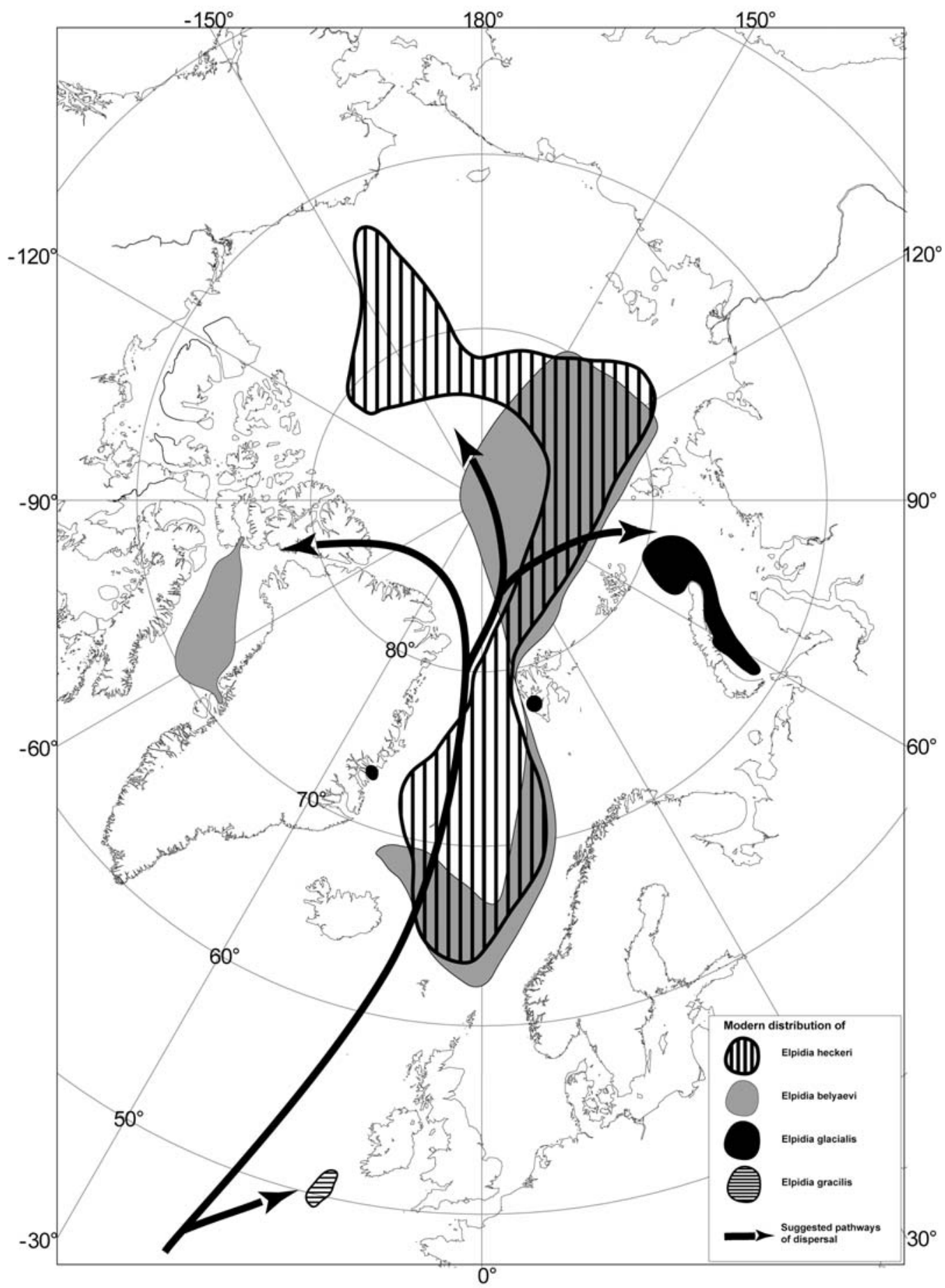

Fig. 4. Distribution of Elpidia in the Northern Hemisphere with suggested pathways of species dispersal. Рис. 4. Распространение рода Elpidia в северном полушарии с обозначением возможных путей расселения видов. 


\section{Discussion}

\subsection{Phylogenetic biogeography of Elpidia}

Three scenarios of colonization of the Arctic Ocean by Elpidia can be suggested.

1) Elpidia originated in the Arctic and from there dispersed around the World Ocean. This hypothesis is not supported by the phylogeny: the clade of Arctic species (clade 2) is not at the base of the tree (Figs. 1, 2).

2) Elpidia originated outside the Arctic and penetrated the Arctic Ocean through the North Pacific. This hypothesis also is not supported, since species in the Arctic clade 2 and the North Pacific species are not closely related. E. hanseni (the Kuril-Kamchatka and Izu Trenches, $8175-9735 \mathrm{~m}$ ) is in clade 3 (Figs. 1, 2). E. kurilensis (the Aleutian, Kuril-Kamchatka and Japan Trenches, 6410-8100 m), E. longicirrata (the Kuril-Kamchatka Trench, 8035-8345 m) and E. birsteini (the Kuril-Kamchatka and Izu Trenches, 8060-9345 m) form a monophyletic clade 5 (Figs. 1,2) on the strict consensus tree supported by two homologies (dorsal ossicles without vertical apophyses predominate). $E$. minutissima (the Aleutian trench and Bering Sea, 4100-5740 m) forms a polytomy with clades 2 and 3, and four other Elpidia species show no close relationships with the Arctic clade 2.

3) Elpidia originated outside the Arctic and colonised the Arctic Ocean through the North Atlantic. Monophyletic clade 2 (Figs. 1, 2) includes exclusively Arctic species and shows no close relation with other Elpidia species on the strict consensus tree forming a basal polytomy. On the majority rule tree (Fig. 1B) and MPT1-3 the monophyletic clade 6 (Fig. 2A-C) combines three Arctic species with the north Atlantic E. gracilis, supported by one homoplastic synapomorphy (presence of rods with maximum diameter $>35 \mu \mathrm{m})$. Elpidia gracilis is distributed in the Antarctic and the North-East Atlantic at bathyal and abyssal depths (1484$6145 \mathrm{~m}$ ). The depth range of E. gracilis in the North-East Atlantic is limited to $1484-4000 \mathrm{~m}$.
We therefore suggest that Elpidia invaded the Arctic from the bathyal or upper abyssal of the North Atlantic.

Although none of the scenarios of Arctic colonization by Elpidia can be confirmed with confidence, we suggest that penetration through the North Atlantic (third scenario) is more likely. This is supported by close relationship between E. gracilis and the Arctic species. The North Pacific species of Elpidia are specialized forms, inhabiting abyssal and hadal depths. Presumably the Bering Strait serves as a barrier preventing dispersal of these species into the Arctic basin.

Belyaev (1971, 1975) discussed the biogeoraphical history of the genus Elpidia, based on morphology of the species. He suggested that the genus originated in the Antarctic and eurybathic ancestral forms dispersed around all the oceans. These forms evolved into the recent stenobathic species mainly distributed locally at hadal depths. Four groups of species in the genus were distinguished by Belyaev. One of them, closely related to ancestral dispersal forms, is characterised by slender ossicles resembling the juvenile type. The other three groups included specialised hadal species from deep-sea trenches of the Pacific and the Antarctic, all with modified ossicles. Belyaev suggested three main pathways of dispersal from the Antarctic: along the west and the east Pacific and through the Atlantic. Colonization of the Arctic was suggested through the Atlantic (Belyaev, 1975).

Our results confirm that slender and smooth ossicles with high vertical apophyses (juvenile type, characters 14-20) are plesiomorphic, therefore this type of ossicles indeed could have been characteristic for ancestral dispersal forms. Also we can confirm close relationships between some "specialized" species according to Belyaev. However, of the three pathways suggested by Belyaev (1975), only dispersal through the Atlantic is supported by our results.

\subsection{Phylogenetic biogeography of Paradiopatra}

The low resolution of the phylogenetic reconstructions of Paradiopatra (Fig. 4) did not 

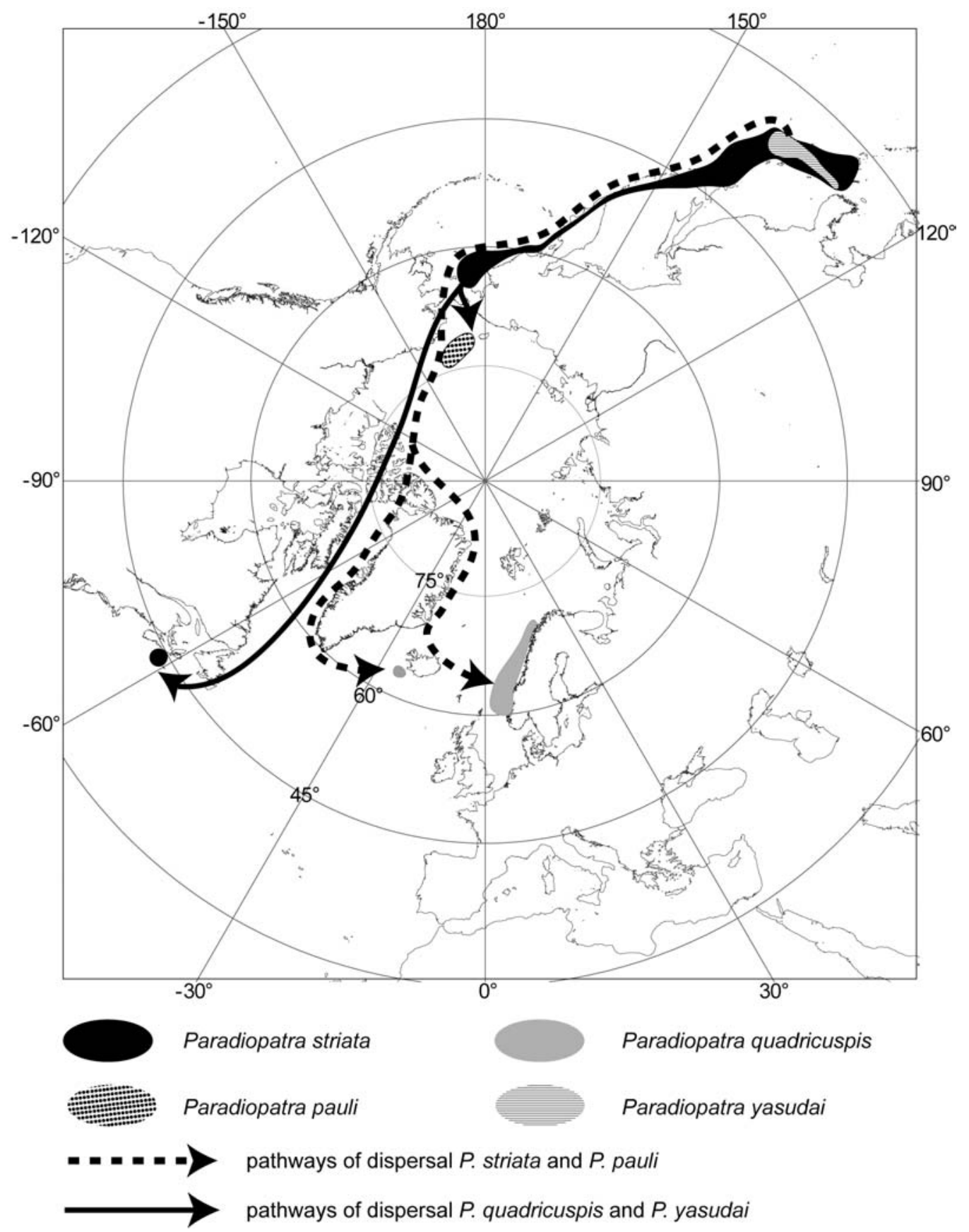

Fig. 5. Distribution of Paradiopatra in the Northern Hemisphere with suggested pathways of species dispersal.

Рис. 5. Распространение рода Paradiopatra в северном полушарии с обозначением возможных путей расселения видов. 
permit identification of the most basal species in the genus, thus the centre of origin of the genus remains unknown. However, a number of wellsupported clades suggest several potential dispersal pathways in the Northern Hemisphere. The species pairs $P$. striata/P. pauli and $P$. yasudai/P. quadricuspis support a hypothesis of colonization of the Arctic and the North Atlantic by Pacific fauna. Both clades comprise representatives from the North Pacific and the North Atlantic/Arctic with a large gap between their geographical ranges.

Briggs (1974, 1995, 2003, 2004) suggested that the vector of species dispersal was directed from species-rich areas to areas with a lower number of species. Following Briggs, we suggest that the more speciose fauna of the North Pacific could serve as a donor to the species poor fauna of the North Atlantic via a trans-Arctic interchange (Briggs, 2003; Mironov, 2006). The distribution of Paradiopatra species confirms this hypothesis. Fourteen species of Paradiopatra inhabit the North Pacific while only nine occur in the North Atlantic (Table 2), suggesting the Pacific origin of P. pauli and P. quadricuspis and the Atlantic representatives of $P$. striata.

Simberholff (1986) assumed that the vector of species dispersion might be related to the actual number of individuals inhabiting donor and recipient areas. It was suggested that invasion is more likely if a source population is larger, compared to invasion from smaller populations. The population of $P$. striata in the Sea of Japan and the Bering Sea is very large and diverse (Budaeva, Fauchald, 2011; Imajima, 1999), whereas only few specimens are known from the better-studied north-west Atlantic. $P$. pauli, most closely related to the Arctic $P$. striata, occurs in the near-Pacific area, thus indicating potential faunal exchange from the North Pacific to the Arctic.

It has been proposed that migration of Pacific fauna took place along the Canadian coast rather than along that of Eurasia (Nesis, 1961; Durham, MacNeil, 1967; Gladenkov, 1978; Vermeij, 1991). The prevalence of the Canadian pathway was explained by the anticlockwise currents in the American Arctic (Canada Ba- sin), favouring migration of species from the North Pacific to the North Atlantic and preventing dispersion of the north Atlantic species in the opposite direction (Hopkins, 1967; Gladenkov, 1978; Vermeij, 1991). In addition, the extensive freshwater outflow of Siberian rivers form a low salinity barrier, preventing transArctic migration of species susceptible to reduced salinity along the Eurasian coast. This hypothesis has been confirmed recently in a study of the genetic differentiation in populations of the northern capelin, revealing dispersal from the North Pacific to the North Atlantic along the Canadian Arctic (Dodson et al., 2007). Following the scheme of the Canadian pathway for shallow-water marine fauna, we suggest dispersal of Paradiopatra from the North Pacific to the North Atlantic along the Canadian Arctic Archipelago (Fig. 5). Penetration into the North-west Atlantic could occur along the west Greenland coast, this pathway also leading to the central north Atlantic (south of Iceland), with an alternative pathway along the east Greenland to northern Europe along the Faroe-Iceland Ridge (Fig. 5).

The geographical range of Paradiopatra fiordica is almost identical with that of $P$. quadricuspis, inhabiting the subtidal and upper bathyal west off Norway and south of Iceland. Both species frequently occur together in same samples (Winsnes, 1985) and usually are confused with each other in identification. However, morphologically $P$. fiordica is very distant from P. quadricuspis. Unlike P. quadricuspis, $P$. fiordica lacks branchiae; has exclusively tridentate rather than bidentate falcigers and subacicular hooks appearing from chaetiger 11-17 rather than from chaetiger 9. Although $P$. fiordica did not form a monophyletic clade with other species of Paradiopatra on the strict consensus tree, we speculate that being morphologically similar to $P$. hispanica and $P$. papillata (Budaeva, Fauchald, 2011), this species could have colonised the Arctic Ocean from the North Atlantic. However, this assumption is not confirmed by the phylogeny of Paradiopatra possibly due to a high ratio of homoplastic characters. 


\section{Acknowledgments}

We would like to thank Alexander Mironov and Andrey Gebruk for invaluable comments on the manuscript. This work was supported by the Russian Foundation for Basic Research grants \#\# 10-04-01687, 12-05-33049. Partial support received from Minobrnauki (Russian Federation), grants \#\# 8664, 8132. This work is part of the project "Arctic marine fauna: data accumulated in Russia" (sub-project of the CoML "Arctic Ocean Diversity" program).

\section{References}

Addison J.A., Hart M.W. 2005. Colonization, dispersal, and hybridization influence phylogeography of North Atlantic sea urchins (Strongylocentrotus droebachiensis) // Evolution. Vol.59. P.532-543.

Anisimova N.A. 1989. Distribution patterns of echinoderms in the Eurasian sector of the Arctic Ocean // Y. Herman (ed.). The Arctic Seas. New York: Van Nostrand. P.281-301.

Belyaev G.M. 1971. [Deep-sea holothurians of the genus Elpidia] // Trudy Instituta Okeanologii Akademii Nauk SSSR [Transactions of the P.P. Shirshov Institute of Oceanology]. Vol.92. P.326-367 [in Russian, with English abstract].

Belyaev G.M. 1975. [New species of holothurians of the genus Elpidia from the South part of Atlantic Ocean] // Trudy Instituta Okeanologii Akademii Nauk SSSR [Transactions of the P.P. Shirshov Institute of Oceanology]. Vol.103. P.259-280 [in Russian, with English abstract].

Bluhm A.B., Ambrose W.G., Jr., Bergmann M., Clough L.M., Gebruk A.V., Hasemann C., Iken K., Klages M., MacDonald I.R., Renaud P.I., Schewe I., Soltwedel T., Bodarska-Kowalczuk M. 2011. Diversity of the arctic deep-sea benthos// Marine Biodiversity. Vol.41. P.87107.

Briggs J.C. 1974. Marine Zoogeography. New York: McGraw-Hill Book Co. 475 p.

Briggs J.C. 1995. Global Biogeography. Amsterdam: Elsevier. 452 p.

Briggs J.C. 2003. Marine centres of origin as evolutionary engines // Journal of Biogeography. Vol.30. P.1-18.

Briggs J.C. 2004. Older species: a rejuvenation on coral reefs? // Journal of Biogeography. Vol.30. P.525-530.

Brundin L. 1966. Transantarctic relationships and their significance, as evidenced by chironomid midges. With a monograph of the subfamilies Podonominae and Aphroteniinae and the austral Heptagyiae // Kongl. Svenska Vetenskaps Academiens Handlingar. Vol.11. P.1-472.

Brundin L. 1972. Phylogenetics and biogeography // Systematic Zoology. Vol.21. P.69-79.

Budaeva N., Fauchald K. 2011. Phylogeny of the Diopatra generic complex with a revision of Paradiopatra Ehlres, 1887 (Polychaeta: Onuphidae) // Zoological Journal of the Linnean Society. Vol.163. P.319-436.
Collins T.M., Frazer K., Palmer A.R., Vermeij G.J., Brown W.M. 1996. Evolutionary history of northern hemisphere Nucella (Gastropoda, Muricidae): molecular, morphological, ecological, and paleontological evidence // Evolution. Vol.50. P.2287-2304.

Crisci J.V., Katinas L., Posadas P. 2003. Historical biogeography. London: Harvard University Press. 264 p.

Dallwitz M.J., Paine T.A., Zurcher E.J. 1999. User's guide to the DELTA Editor. http://delta-intkey.com.

Djakonov A.M. 1945. [On the relationship between the Arctic and the North Pacific marine faunas based on the zoogeographical analysis of the Echinodermata] // Zhurnal obshchey biologii [Journal of General Biology]. Vol.6. P.25-155 [in Russian, with English abstract].

Dodson J.J., Tremblay S., Colombani F., Carscadden L.M., Lecomte F. 2007. Trans-Arctic dispersal and the evolution of a circumpolar marine fish species complex, the capelin (Mallotus villosus) // Molecular Ecology. Vol.16. P.5030-5043

Durham J.W., MacNeil F.S. 1967. Cenozoic migrations of marine invertebrates through the Bering Strait region // D.M. Hopkins (ed.). The Bering Land Bridge. Stanford, California: Stanford University press. P.326349.

Gladenkov Yu.B. 1978. [Marine upper Cenozoic of the northern regions] // Trudy Geologicheskogo Instituta Akademii Nauk SSSR [Transactions of the Geological Institute of the Academy of Science of the USSR]. Vol.313. P.1-194 [in Russian].

Gontar V.I., Denisenko N.V. 1989. Arctic Ocean Bryozoa // Y. Herman (ed.). The Arctic Seas. New York: Van Nostrand. P.341-371.

Gurjanova E.F. 1939. [Contribution to the origin and history of the fauna of the Polar Basin] // Izvestiya Akademii Nauk SSSR, seriya biologicheskaya [Bulletin of the Russian Academy of Sciences. Biology]. Vol.5. P.679-704 [in Russian].

Harrison M.K., Crespi B.J. 1999. Phylogenetics of Cancer crabs (Crustacea: Decapoda: Brachyura) // Molecular Phylogenetics and Evolution. Vol.12. P.186-199.

Hansen B. 1956. Holothurioidea from the depths exceeding 6000 meters // Galathea Report. Vol.2. P.33-54.

Hansen B. 1975. Systematics and biology of the deep-sea holothurians // Galathea Report. Vol.13. P.1-262.

Heding S.G. 1942. Holothurioidea. II. AspidochirotaElasipoda-Dendrochirota // The Danish Ingolf Expedition. Vol.IV. P.1-39.

Imajima M. 1999. Onuphidae (Annelida, Polychaeta) from Japan, excluding the genus Onuphis // National Science Museum Monographs. Vol.16. P.1-115.

Kussakin O.G. 1979. [Marine and brackish-water Isopoda of the cold and temperate waters of the Northern Hemisphere. I. Suborder Flabellifera] // Opredeliteli po faune SSSR [Keys to the fauna of the USSR, published by the Zoological Institute of the Academy of Sciences of the USSR]. Vol.122. 472 p. [in Russian].

Mironov A.N. 2006. Centers of Marine Fauna Redistribution // Entomological Review. Vol.86. Suppl.1. P.32-44. 
Mironov A.N. 2013. Biotic complexes of the Arctic Ocean // Invertebrate Zoology. Vol.10. No.1. P.3-48.

Mironov A.N., Dilman A.B. 2010. [Effect of the East Siberian barrier on the echinoderm dispersal in the Arctic Ocean] // Okeanologiya [Oceanology]. Vol.50. No.3. P.371-386 [in Russian, with English abstract]. English translation: Oceanology. Vol.50. No.3.P.342355 .

Nesis K.N. 1961. [The routes, and the periods of formation, of the interrupted area of distribution of amphiboreal species of marine bottom animals] // Okeanologiya [Oceanology]. Vol.1. P.893-903 [in Russian]. English translation: Deep-Sea Research. Vol.10. P.498-506 (1963).

Nixon K.C. 2002. WinClada ver. 1.0000 Published by the author, Ithaca, NY, USA. http://www.cladistics.com/ about_winc.htm.

Palumbi S.R., Kessing B.D. 1991. Population biology of the trans-Arctic exchange: Mitochondrial DNA sequence similarity between Pacific an Atlantic sea urchins // Evolution. Vol.45. P.1790-1805.

Petryashov V.V. 2009. [Biogeographical division of the Arctic and North Atlantic based on the fauna of mysids (Crustacea: Mysidacea)] // Biologia morya [Russian Journal of Marine biology]. Vol.35. P.87106 [in Russian, with English abstract].

Rogacheva A. 2007. Revision of the Arctic group of species of the family Elpidiidae (Elasipodida, Ho- lothuroidea) // Marine Biology Research. Vol.3. P.367-396.

Simberholff D.S. 1986. Introduced insects: a biogeographic and systematic perspective // H.A. Mooney, J.A. Drake (eds.). Ecology of biological invaders of North America and Hawaii. New York: Springer. P.3-26.

Smirnov A.V. 1994. Arctic echinoderms: composition, distribution and history of the fauna // B. David, A. Guille, J.D. Féral, M. Roux (eds.). Echinoderms through time. Proceeding of the Eighth International Echinoderm Confefence, Dijon, France, 6-10 September 1993. Rotterdam: Balkema. P.135-142.

Väinölä R. 2003. Repeated trans-Arctic invasions in littoral bivalves: molecular zoogeography of the Macoma balthica complex // Marine Biology. Vol.143. P.935-946.

Vermeij G.J. 1991. Anatomy of an invasion: the transArctic interchange // Paleobiology. Vol.17. 281-307.

Wares J.P. 2001. Biogeography of Asterias: North Atlantic climate change and speciation // Biological Bulletin. Vol.201. P.95-103.

Wares J.P., Cunningham C.W. 2001. Phylogeography and historical ecology of the North Atlantic intertidal // Evolution. Vol.55. P.2455-2469.

Winsnes I.M. 1985. The use of methyl green as an aid in species discrimination in Onuphidae (Annelida, Polychaeta) // Zoologica Scripta. Vol.14. P.19-23. 